Бұл CC BY-NC-ND лицензиясы бойынша қол жетімді мақала (https://creativecommons.org/licenses/by-nc-nd/3.0/) «Ғылымның өзекті мәселелері» - Халықаралық практикалық интернет- конференция материалдары

Басылым II, Қараша 2019

ISBN 978-601-323-144-0

https://doi.org/10.31643/2019.014

\author{
Рымбай Ақбота \\ Қазтұтынуодағы Қарағанды Экономикалық университеті \\ E-mail: Akbota.rymbai@mail.ru \\ ORCID ID 0000-0002-9274-5389
}

\title{
Халықаралық тәжірибе бойынша Ресей мен АҚШ-тын инфляциямен күрес әдістерін салыстырмалы талдау
}

Түйін: Бұл мақалада Ресей мен АҚШ сияқты елдердің инфляция деңгейлері талданып, деректер бойынша диаграммалар ұсынылған. Сондай-ақ осы елдердің инфляциясымен күрестің негізгі әдістері белгіленген. Инфляция әр бір елдің экономикасы үшін қорқынышты құбылыс, ал оны мінсіз жеңу жолдарын экономистер әлі күнге шейін тапқан жоқ. Мақала да сол себепті халықаралық тәжірибеге сүйеніп жазылды. Деректерге негізделе отырып Қазақстанның да инфляциялық жағдайы көрсетіледі. Қазақстандық инфляцияның бірнеше ерекшеліктері айқындалды. Инфляцияның алдын алу және күресудің жолдары анықталды.

Түйін сөздер: инфляцияға қарсы саясат, күрес, мемлекет, инфляция, әдістер, инфляция деңгейі, қаржы.

\section{Kiрicпе}

Кез келген нарықтық экономикада инфляция сияқты құбылыс бар. Ол қоғам өмірінің барлық салаларына әсер ететін маңызды макроэкономикалық көрсеткіштердің бірі болып табылады. Көбінесе мамандарға экономикалық болжамдар жасау қиынға соғады, өйткені нарықтық экономика, қаржы нарығы өзгеруде, кірістер қайта бөлінуде. Жоғары деңгей инфляция, әсіресе мемлекет нашар бақылайтын - қоғамдағы әлеуметтік шиеленістің артуына алып келетін өте қауіпті процесс, өмір сүру сапасын төмендетеді. Экономикалық қатынастардың тарихы туралы оқу әдебиеттерінде авторлар инфляция құбылысы ақша пайда болуымен пайда болды деген ұстанымды ұстанады. Бұл әр түрлі уақыт кезеңдерінде инфляция табиғатын түсіндіретін әртүрлі тәсілдердің осындай үлкен санын көрсетеді. Инфляция деп бағаның өсуінде көрінетін артық ақша массасымен нарықты асыра толтыруы түсініледі. Басқаша айтқанда, бұл сұраныс пен ұсыныстың теңгерімсіздігі. Инфляция процесінде тауарлар мен қызметтерге қатысты ақша бірлігі құнсызданады.

\section{Инфлация}

Инфляциялық процестер көздерінің бірі ауыр өндірістің тез дамуы кезінде тұтыну секторы салаларының артта қалуы болып табылады. Сұраныс пен ұсыныстың арасындағы теңгерімсіздік, сондай-ақ табыстан асатын мемлекеттік бюджеттің үлкен шығындарынан туындауы мүмкін. Сондай-ақ инвестициялар мен жалақының озыңқы өсуі де ерекше әсер етеді. Әлемдік экономикада теңгерімсіздікке әкелуі мүмкін үш негізгі күш бөлінеді:

$>$ Айналыстағы ақшалай массаның өзгермеген көлемі кезінде жалпы ішкі өнімнің қысқаруы.

$>$ Ақша эмиссиясының орын алуына байланысты мемлекеттік шығыстардың өсуі.

$>$ Несие беру көлемін аса көбейту.

Қазіргі уақытта инфляция барлық елдерді қамтыған күрделі процесс болып табылады. Инфляция өсуінің жоғары қарқыны елдің экономикалық дамуының нашарлауына, ұлттық ақша бірлігінің құнсыздануына әкеп соғады. Қазіргі инфляция нарықтағы мүлдем әртүрлі факторлар мен жағдайларға байланысты. Инфляция қиын экономикалық құбылыс болып табылады, онымен күресу қажет. Күрестің негізгі түрі мемлекеттің инфляцияға қарсы саясаты болып табылады.

Инфляцияға қарсы саясат-инфляцияға қарсы күреске бағытталған мемлекеттік реттеудің іс-қимыл кешені. Антиинфляциялық саясаттың әртүрлі түрлері бар:

$>$ Дефляциялық саясат-оның мағынасы мемлекеттік шығыстарды төмендету және ақша массасын шектеу жолымен ақшалай сұранысты шектеуден тұрады. Бірақ, сондай-ақ нарықтағы дағдарысты жағдайдың туындауы мүмкін болатын кемшіліктер бар. 
Табыс саясаты-оның әдістері жалақы өсуінің шектерін белгілеуді және бағаны бақылауды көздейді. Мұндай саясат нарықтағы тауарлардың тапшылығына әкелуі мүмкін.

\section{Талдау}

Төменде келтірілген диаграммаларда (кесте 1, кесте 2) Ресей, АҚШ сияқты елдерде инфляция деңгейі қалай өзгергенін қарастырайық. Бірінші кестеде 90-шы жылдардың басында қалыптасқан жағдайға байланысты Ресейдегі инфляция деңгейі өте жоғары болды. Сондай-ақ, салық базасы қысқарды, демек, елдегі дағдарысқа алып келді, қолма-қол ақша үлесі 30\% - дан асты, бұл көлеңкелі экономиканың дамуына ықпал етті. Инфляцияны төмендету үшін мемлекет ақша-несие саясатын жүргізе бастады. 2000 жылға қарай инфляция деңгейі шамамен бір деңгейде болды (15-20\%). Айта кету керек, 2016 жылы көрсеткіш 5,4\%-ға дейін төмендеді. Бірақ 2017 жылғы Росстаттың мәліметтері бойынша, инфляция талдаушылардың болжамынан төмен болды және 2,5\% құрады.

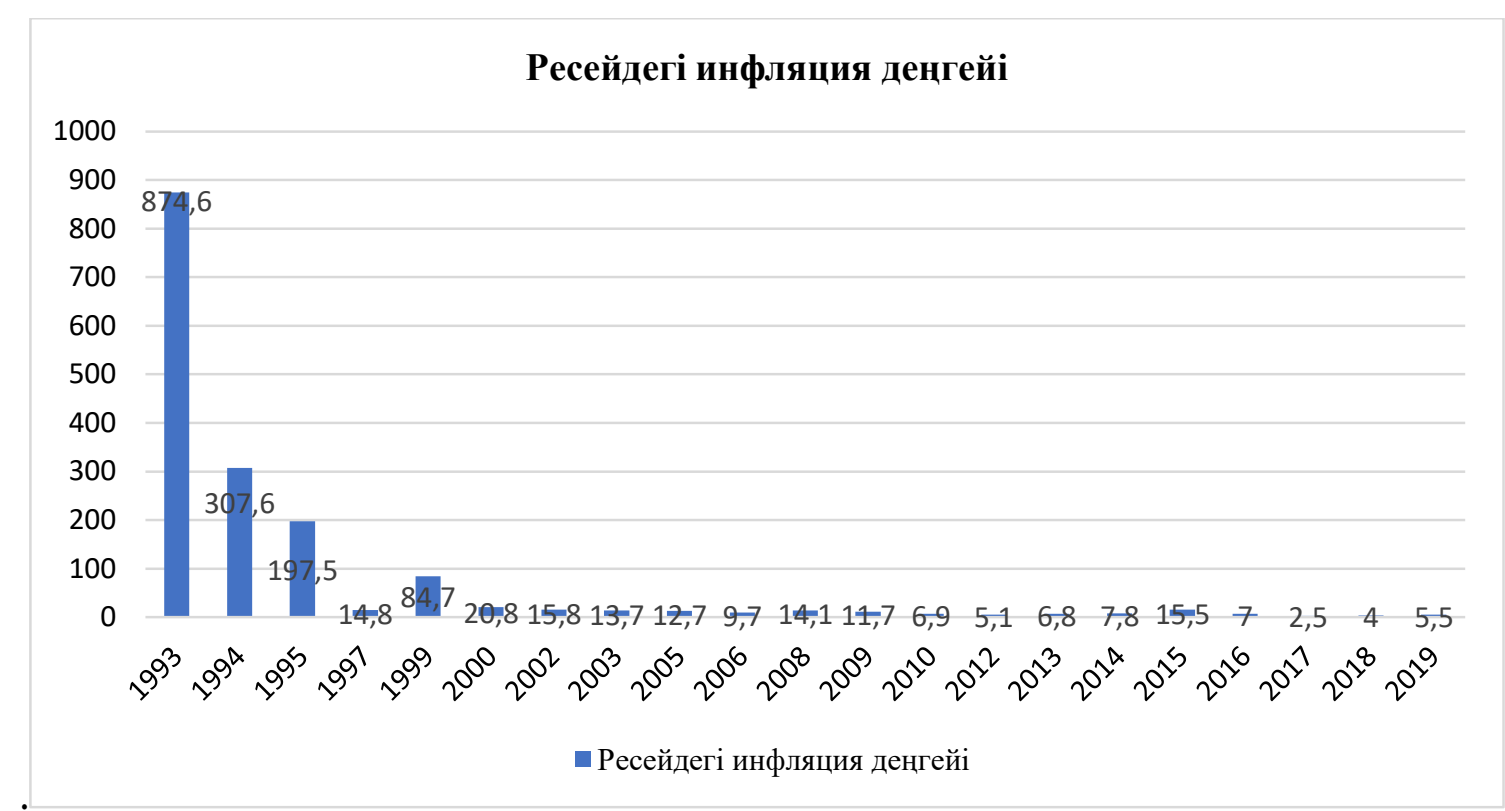

Кесте 1 Ресейдегі инфляция деңгейінің өзгеруі

Екінші кестеде АҚШ-тағы инфляция деңгейі шамамен бірдей және шамамен 2-4\% - ды құрады. Ал 2008 жылы инфляция деңгейі осы уақыт кезеңінде ең жоғары болды, бұл мұнай, нан, кофе және т.б. бағаларының күрт өсуінен туындады, бірақ 2009 жылы әлемдік нарықтағы евроға және басқа валюталарға доллардың нығаюы басталғаннан кейін бағаның өсу қарқыны күрт қысқарды және тиісінше инфляция көрсеткіші -0,3\% - ға дейін күрт төмендеді. Сарапшылар бағаның күрт төмендеуі дефляцияға әкелуі мүмкін деп санайды, сондықтан Америка экономикасында дефляциямен күрес ең басты міндеттердің бірі болып табылады.

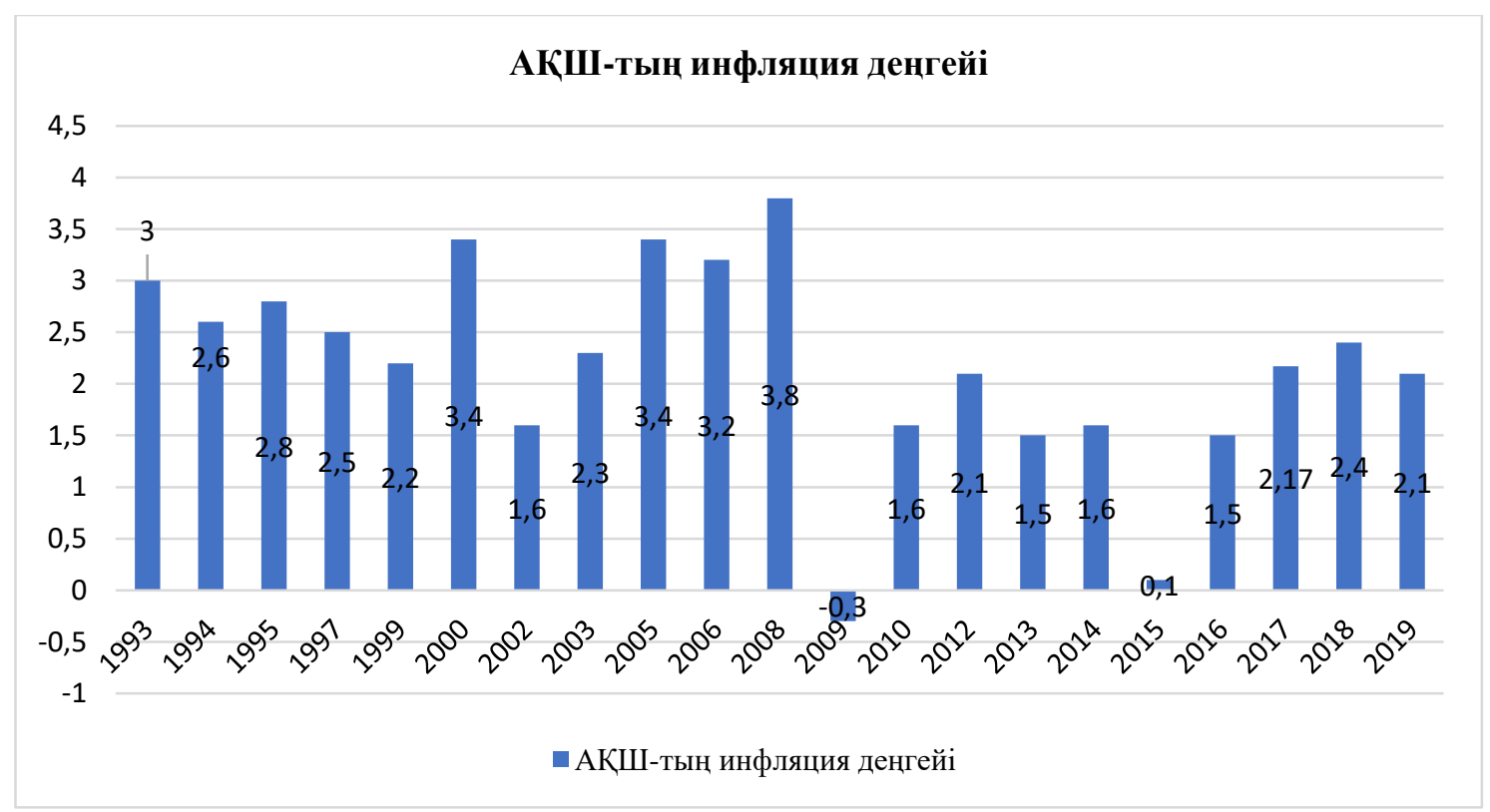

Кесте 2 АҚШ-тағы инфляция деңгейінің өзгеруі 
Біз бүгінгі таңда басты бәсекелестердің бірі болып табылатын мүлдем басқа екі елді талдап, инфляциямемлекет қаржысына, ақша-несие жүйесіне және жалпы ел экономикасының жағдайына кері әсер ететін қазіргі әлемдегі өте күрделі мәселе. Сондықтан әрбір ел онымен күресуге тырысады, сондықтан да мемлекеттің негізгі міндеттері антиинфляциялық бағдарламаларды әзірлеу және оларды іске қосу болып табылады.

Қазақстандағы инфляция кеңестік кезеңге дейінгі және посткеңестік кезеңдегі экономикалық және әлеуметтік аспектілердегі республиканың ерекшелігімен байланысты. Біріншіден, ол өндірістің күрт құлдырауы жағдайында дамиды. Қазақстандағы инфляцияның тағы бір ерекшелігі - бұл тауарлар мен қызметтерге бағалар жасанды түрде төмен болған, бірақ айтарлықтай тапшылық болған кезде «басылған» инфляция жағдайынан туындады. Инфляцияның «басылған» күйі қалыпты экономика үшін қолайсыз әдістермен - шығынсыз салалар мен салаларды толық субсидиялау арқылы қолдау көрсетілетін макроэкономикалық тепе-теңдіктің пайда болуын тудырады. Процесс өндірістік, техникалық және тұтынушылық мақсаттағы өнімді сатып алу мүмкін болмайтын кәсіпорындардан, ұйымдардан және тұрғындардан қомақты қаражат жинауымен қатар жүрді. Оның негізінде бұл сұраныс инфляциясы, яғни экономикалық агенттер мен халықтың сұранысының артуы ұсыныс жағынан қанағаттандыра алмады.

Келесі ерекшелік Қазақстан халық шаруашылығының шикізаттық сипаты болып табылады, бұл тұтыну тауарлары бойынша ішкі нарықтың сыртқы нарықтарға тәуелділігіне себепші болады. Бұл жағдайда инфляция екі құрамдас бөліктен тұрады. Біріншіден, импортталатын өнімнің кеден бажы есебінен қымбаттауы. Екіншіден, бір жағынан , шикізат өнімдерінің құны мен бағасындағы айырмашылық және екінші жағынан дайын тұтыну немесе инвестициялық тауарлар. Бұл фактор мемлекеттің төлем балансының жай - күйі-оның шығыстар мен кірістер шоттары арасындағы теріс айырмашылық арқылы көрінеді. Теңгерімге сыртқы қарыздар, активтерді сату, мемлекеттің ресми валюталық резервтерін төмендету есебінен қол жеткізіледі. Алайда, аталған шаралар экономикадағы макроэкономикалық тұрақтылықты бұзады, шаруашылық тұрақтылыққа қол жеткізуге ақша қаражатын ірі ішкі салымдарды талап етеді және инфляцияның жаңа толқынын тудырады.

Қазақстанда инфляцияның дамуына инфляциялық әсер тудыратын жаңа салықтарды - 28\% бастапқы ставкамен қосылған құн салығын, акциздерді, экспорттық және кеден баждарын, өнімнің өзіндік құнына, экономиканы қайта құру қорына, халықты жұмыспен қамтуға жәрдемдесудің мемлекеттік қорына енгізілетін қаражат аударымдарын енгізу, әлеуметтік сақтандыруға аударымдарды күрт ұлғайту сияқты қаржылық және әлеуметтік іс-шараларды тез өткізу ықпал етті. Нарықтық экономикасы дамыған елдердегі қосылған құн салығы артық инвестициялық сұранысты тежеудің, оны тұтынушылық жүйеге ауыстырудың құралы болып табылады. Бұл қайта өндіру дағдарысына жол бермеу үшін қажет. Қазақстанда инвестициялық сұраныстың төмендеуі, оның қосымша қысқаруы қосылған құн ставкасы әсерімен байланысты, бұл жинақтау мәселесін одан әрі қиындатқан және халық шаруашылығына инвестициялардың төмендеуінің факторы болып табылады.

Инфляцияны еңсерудің мынадай шарттарын атап өту қажет: инфляция деңгейі жоғары болған сайын, онымен күресу қиын; инфляцияны төмендетудің барлық жолдары әлеуметке қарсы болып табылады, яғни халықтың басым көпшілігі үшін ауыр. Инфляцияны еңсеру жөніндегі іс-шаралар кешені қоғамның жұмыс істеуінің өндірістік-экономикалық, әлеуметтік, құқықтық, институционалдық салаларының әртүрлі тараптарына ықпал етуді қамтиды, алайда олардың шешуші бөлігі базалық, өндірістік-экономикалық болып табылады.

\section{Қорытынды}

Жоғары айтылғандардың барлығын қорытындылай келе, теориялық тұрғыдан инфляцияны несие эмиссиясын тоқтату жолымен еңсеруге болады, бірақ біздің жағдайда тек өндірісті тоқтату бағасымен ғана. Шаруашылықтың өмірлік маңызды салаларында немесе белгілі бір әлеуметтік топтардың қысымымен сыни шамаларға жеткен кезде өндірістің құлдырауына әкеп соғатын эмиссияны қысқарту үкімет эмиссияны қайта бастауға мәжбүр етеді, одан кейін бағалардың кезекті көтерілуі орын алады. Бұл процесс дәйекті түрде қайталанады: микродеңгейде нарықтық бәсекелестіктің болмауы және нарықтық ортаның дамымауы инфляциялық толқындардың туындауына алып келеді. Мұндай экономикалық саясатты сақтай отырып, автоматты нарықтық тетіктерді қосуға ғана есептегендегі жағдай шексіз ұзаққа созылып, елдің экономикалық әлеуетінің бұзылуына алып келеді. Келесі әдіс, салықтарды ұлғайту, мемлекеттік шығыстарды қысқарту және осының негізінде мемлекеттік бюджет тапшылығын төмендету жолымен жүргізілетін инфляцияға қарсы фискалдық саясат. Салықтық инфляцияға қарсы саясат салық ауыртпалығын, әсіресе жанама салық салуды қысқарту болып табылады. Жоғары салықтар іс-әрекетінің басқа нұсқасы-олардың өндіріске қысым, бұл ұсынысты шектейді. Үшінші, елеулі салық ауыртпалығы, әдетте, салық жүйесін қиындататын көптеген салықтардың әрекетімен байланыстырылады,бұл салықтан жалтаруға әкеледі. Сондықтан инфляция кезінде қарапайым және сенімді салық жүйесі дұрыс.

\section{Алғыс}

Осы мақаланы жазуда ғылыми бағыт берген ҚҚЭУ университетінің экономикалық теория, мемлекеттік және жергілікті басқару кафедрасының доценті, философия ғылымдарының $\mathrm{PhD}$ докторы Кернебаев Айдын Сапаровичке алғыс айтамын. 


\title{
Rymbai Akbota
}

Karaganda economic University of Kazpotrebsoyuz, Kazakhstan

E-mail: Akbota.rymbai@mail.ru

ORCID ID 0000-0002-9274-5389

\section{Comparative analysis of methods of combating inflation in Russia and the United States by international experience}

\begin{abstract}
This article analyzes the inflation rates in countries such as Russia and the United States, presents charts on the data. The main methods of combating inflation in these countries are also defined. Inflation is a terrible phenomenon for the economy of every country, and economists have not yet found the way to its flawless victory. Therefore, the article was written on the basis of international experience. On the basis of the data, the inflationary state of Kazakhstan is indicated. Several features of Kazakhstan inflation are defined. The ways of inflation prevention and struggle are defined.
\end{abstract}

Keywords: anti-inflationary policy, struggle, state, inflation, methods, inflation level, financial.

Мақалаға сілтеме: Рымбай А. (2019) Халықаралық тәжірибе бойынша Ресей мен АҚШ-тың инфляциямен күрес әдістерін салыстырмалы талдау. «Ғылымның өзекті мәселелері» Халықаралық практикалық интернет- конференция материалдары / Materials of International Practical Internet Conference "Challenges of Science". ISBN 978-601-323-144-0. Басылым II, 2019. Бет: 76-79. https://doi.org/10.31643/2019.014

\section{Пайдаланылған әдебиеттер}

[1] МатвееваТ. Ю. Макроэкономикаға кіріспе: оқу құралы / Экономика Жоғары мектебінің баспа үйі / Мәскеу, 2010 бет 512

[2] Белоусов Е. С. РФ-дағы Инфляция және инфляцияға қарсы саясат / кітап зертханасы / Мәскеу к. 2009 Б. 60

[3] Гула Д. М. Инфляция және әлеуметтік қақтығыстар /кітап зертханасы / Мәскеу қ. 2012-153б.

[4] Әлем елдеріндегі инфляция деңгейі 2019 жылғы көрсеткіш. [Электронды ресурс] / кіру режимі: http://svspb.net/danmark/infljacija-stran.php

[5] Федералдық мемлекеттік статистика қызметі 2019 жылғы көрсеткіш. [Электронды ресурс] /кіру режимі: http://www.gks.ru/

[6] Бактыбекова Д. К., Ибраимханова А.Е. Мемлекеттің инфляцияға қарсы саясаты // Инновациялық менеджменттің теориясы мен практикасы: отандық және шетелдік тәжірибе. Қарағанды. 2013 